UDK 636.085.33:636.085.552 (c) (i) Dris Open Access

DOI:

B. Yegorov, Dr. of Technical Sciences, Professor, E-mail: bogdanegoroff58@gmail.com https://orcid.org/0000-0001-7526-0315, ResearcherID: Q-1365-2015, Scopus Author ID: 56578802600

N. Batievskaya, Post-graduate student, E-mail: natabatievskaya@gmail.com https://orcid.org/0000-0002-9380-2891, ResearcherID: J-5254-2015

Odessa National Academy of Food Technologies, 112, Kanatna Str., Odessa, 65039, Ukraine Department of Feed and Biofuel Technologies, Tel. +048-712-40-88

\title{
QUALITY ASSESSMENT OF COMPOUND FEEDS IN THE FORM OF MIXTURE CRUMBS
}

\begin{abstract}
As the development of the feed industry is characterized by the intensification of technological processes aimed primarily at improving sanitary quality, the methods of preliminary wet-heat preparation of mixed fodder, in particular, the application of expansion to the granulation process, has been presented in the article. The effect of heat treatment on the nutrient absorption of individual ingredients of compound feed has been the subject of many research. In general, the wet-heat treatment of compound feed can improve the digestibility of nutrients, including proteins, amino acids and carbohydrates.

The purpose of the work and the tasks of research were set. The purpose the work was introduction of advanced technology in production compound feed in the form blend of crumbs and determination of their zootechnical quality. The generalization of the conducted analytical and experimental studies allowed develop the advanced of technology granulation in the form blend crumbs, which will increase the output of finished products.

Was developed biological value assessment and assessment of livestock value compound feed in the form blend of crumbs. Studies have been conducted. Experimental studies were conducted at the Odessa National Academy of Food Technologies. Industrial approbation of the developed, advanced technology production compound feed in the form blend of crumbs, was done in industrial conditions of a branch of a public joint stock company "State Food and Grain Corporation of Ukraine" "Izyumsky plant bakery products".

A biological experiment was conducted on laboratory animals at the base of the biochemistry laboratory of the Institute of Dentistry and Oral and Maxillofacial Surgery of the Academy of Medical Sciences of Ukraine. Zootechnical studies, to evaluate the productive action effectiveness compound feed in the form blend of crumbs for young broiler chickens, were carried out under industrial conditions of the "Grain Club". Thus, efficiency of use compound feed in the form blend of crumbs, has been evaluated in experiments on white rats Wistar line (biological assessment), and Cobb 500 cross broiler chickens (zoological assessment).
\end{abstract}

Keywords: mixed fodder industry, quality assessment, technology of granulation, granules, granulated crumb, expanded crumb, compound feed in the form blend of crumbs.

\section{Introduction}

The feed industry, like many other sectors of the food and processing industry, is experiencing significant changes. Despite the general growth in the production of compound feeds, structural changes in the assortment of products are observed, which were caused by changes in animal husbandry and poultry farming.

The constant rise in electricity, fuel, gas prices force population and producers to resort energy-saving activities. The development and implementation of energy-efficient technologies seems relevant, which would reduce their total energy intensity without reducing production volumes in all sectors of the agroindustrial complex of Ukraine, in particular in feed production. $[1,2]$

In this way, it became necessary to search for a new, effective concept of change in the structure of the existing granulation technology of compound feeds for its comprehensive improvement, to solve problems that are considered.

Literary review

One of the indicators, which characterizes the food security of the state, is indicator of consuming norms by the population of Ukraine basic food products, including meat products. Since 1990, Ukraine has had meat production at the level of world standards $(82.4 \mathrm{~kg}$ per person per year). According to "ProAgro", in 2019, Ukraine exported 100 thousand tons of compound feeds to 180.1 million. Imports during this period amounted to 5.5 thousand tons. In the main, aodder additives, premixes and feed mixtures from Europe and China are imported in Ukraine. In recent years there has been an increase in demand for livestock products (meat, milk and fish). Usually, growth in production is observed, especially in countries that are developing, while the developed world remains more or less stable. USA is one of the largest producers of compound feeds in 2015-2019. Global compound feeds production provides an approximate annual turnover of more than 400 billion.

The Food and Agriculture Base United Nations believes that by 2050 the demand for food will increase by $60 \%$, it is expected that livestock production in 2010 2050 will increase by about $1.7 \%$ per year, moreover, the projected growth in meat production by almost $70 \%$, milk production by $55 \%$, fish production by $90 \%$. 


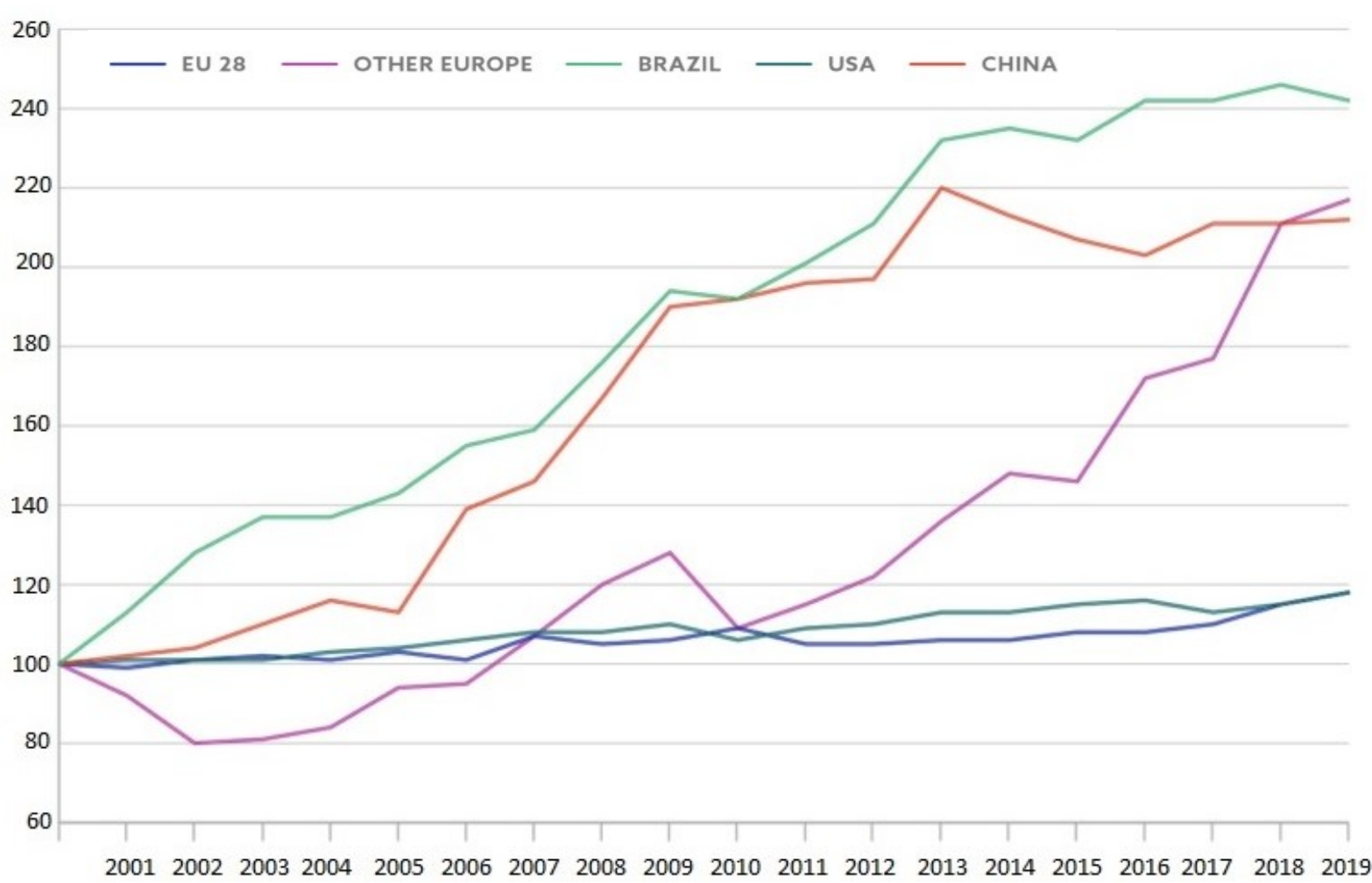

Fig. 1- Statistics of compound feeds production in the world, from 2001 to 2019, [1, 2]

Since, human nutrition depends on high-quality feeding of animals, it is very important to feed agricultural animals with high-quality compound feed, that the population consumed quality animal products.

The feed industry is one of the most competitive sectors in the agricultural sector (Fig. 1).

In 2019 , the world compound feeds production amounted to about 900.5 million. tons of compound feeds. [2, 3] One of the largest producers of Asian compound feeds is Charoen Pokphand - a Thai company that produces 18 million tons of compound feeds in different parts of East Asia. World compound feeds production in 2019 reached approximately 1 billion tons (Fig. 2). [1, 2, 3].

The feed industry of Ukraine is quite significant in the agro-industrial complex of the country. The industry provides livestock and food industry development. Facility of the feed industry produce feed,

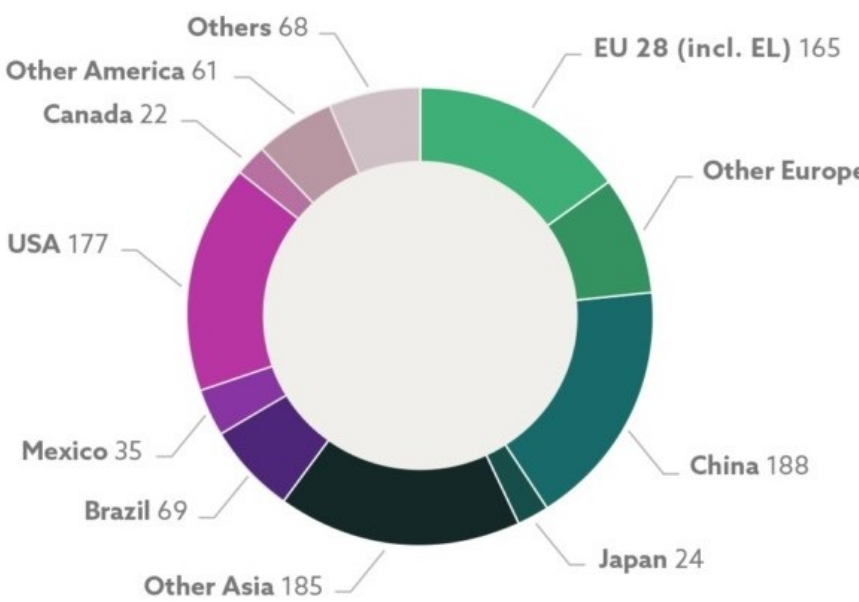

Figure 2 - Production of animal feed in the world, 2019, [2,3] feed concentrates, protein-vitamin and protein-mineralvitamin supplements, premixes and whole milk replacers and other feed products. The feed industry is quite promising on account of the existence of a powerful raw material base in Ukraine, but it strongly depends on the state of animal husbandry and poultry farming in the country. Leaders of compound feeds production in Ukraine for 2016-2020 are Kiev (25-30\%), Cherkasy (15-19\%), Dnipropetrovsk (12-15\%) regions. Market leaders from 2012 to 2016 were, on average, «Katerinopolsky elevator», «Mironovsky elevator», «Complex Agromars». [4, 5, 6]

The traditional process of compound feeds production includes the following technological processes (Figure 1), such as cleaning the components of grain and protein raw materials, preliminary grinding of components, weighing and dosing, mixing the finished mixture of components, obtaining loose compound feeds. Loose compound feeds moistened with subsequent granulation.

Among the main drawbacks of using traditional granulation technology are the following: Also, with 9 traditional granulation technology, the yield of granulated crumb is low in percentage terms (not more than $70 \%$ ), which leads to the re-granulation of the product of the mealy fraction, which increases the unit cost of electricity for the process. That is, the main disadvantage is the high unit cost of electricity for this process. The existing domestic technological lines for granulating and pelletizing compound feeds have a relatively high productivity and, at the same time, a high energy intensity for producing granulated compound feeds.

Granulation allows you to provide stable uniformity, improve sanitary and hygienic parameters, increase nutritional value, increase shelf life, and improve the physical properties of the components of the 
compound feed. However, despite all the advantages, the granulation lines that exist have relatively high performance and, at the same time, high unit costs of electricity. The practical application of the pre-expanding before granulation has established itself thanks to positive indicators. This process provides sanitized compound feeds without destroying vitamins and nutrients. In the product that is processed in the expander, you can add a large amount of liquid components (up to $15-20 \%$ ), while sometimes there is a need to dry the processed product. With this processing of compound feed in the expander, the performance granulator increases significantly.

For example, in the modern production «Vinnytsia Poultry Farm» namely the branch «On-farm complex for the production of compound feed». A reduction in energy consumption was achieved, but in general the effect was not high on the granulation line. Such lines are used in enterprises, but when it comes to large-scale production and sales, the question of energy costs is associated with economic feasibility. [6, 7]

On the basis of the conducted literature and patent examinations should be said that the development of technology to improve the granulation process will not only improve the nutritional and sanitary quality of compound feed products, but will also increase the productive effect of compound feeds and reduce the specific energy consumption. [8]

\section{Formulation of the problem}

The purpose the work is to introduction of advanced technology in production compound feed in the form blend of crumbs and determination of their zootechnical quality.

To achieve this aim, the research objectives have been defined:

- to development improve granulation technology for production compound feed in the form blend of crumbs;

- to carry out biological value assessment compound feed in the form blend of crumbs.

- to carry out assessment of livestock value compound feed in the form blend of crumbs.

\section{Materials and methods}

Experimental studies were conducted at the Odessa National Academy of Food Technologies. Industrial approbation of the developed, advanced technology production compound feed in the form blend of crumbs, was done in industrial conditions of a branch of a public joint stock company "State Food and Grain Corporation of Ukraine" "Izyumsky plant bakery products".

\section{Results of the study and their discussion}

1. To development improve granulation technology for production of compound feeds in the form granulated crumb and expanded crumb.

A number of studies were conducted at the department of technology of animal feed and biofuel ONAFT, and the following technological solution was proposed. Traditional granulation technology includes, all $100 \%$ of the recipe for loose compound feed, it is moistened, expanded and granulated to obtain only crumbs from granules. (fig. 3, scheme A). Our advanced granulation technology differs from the traditional one, because we get a separate product, an expandate, this reduces the load on the granulator, it is not $100 \%$ loaded, getting expanded crumb and mixing with granulated crumb. (fig. 3, scheme B). [8, 9, 10]

The developed technology production granulated compound feed in the form blend granulated crumb and expanded crumb provides: expansion raw materials, separate granulation prepared raw materials, getting granule, getting granulated crumb, getting expandate, getting expanded crumb and mixing crumb getting a blend granulated crumb and expanded crumb.

The finished loose compound feed is processed in moisturizer, where it is heated to a temperature of $+50{ }^{\circ} \mathrm{C}$ to $+85{ }^{\circ} \mathrm{C}$ for $5-10$ seconds and moistened content of $18-22 \%$. Exercise of such processing provides compound feed thermo-plastic properties. The next stage of processing is carried out using expander. Moisture compound feed in expander is $16-22 \%$, temperature of + $110^{\circ} \mathrm{C}$ to $+120^{\circ} \mathrm{C}$. The resulting product - the expandate has a moisture content of $13-14 \%$, its temperature is approximately $85-95^{\circ} \mathrm{C}$. Expandate has the form of pieces, sizes from $20-50 \mathrm{~mm}$. Part of the expandate is cooled, crushed and sieved, to obtain expanded crumb, and part granulated in a granulator under standard processing conditions.

In the granulator under the influence of high pressure and temperature occur structural-mechanical and chemical transformations of the product, increases the degree of absorption of animal nutrients. The compound feed treated with steam has a moisture content of $15-18 \%$ and a temperature of $60-90{ }^{\circ} \mathrm{C}$, steam pressure, as a rule, is $0.2-0.5 \mathrm{MPa}$, steam consumption is 50 $80 \mathrm{~kg} /$ ton. $[11,12,13]$

The granules obtained after granulation have a temperature of $60-80{ }^{\circ} \mathrm{C}$, they are sent to the cooling stage. After this stage, chilled products are obtained in the form of granulated compound feed, which are crushed. Next, the grinding products (granulated crumb and expanded crumb) are sifted onto separate screeners to control the amount of products. The grinding products are sent to a separator, in which two sieves are installed: upper is №30. Descent from upper sieve sent for regrinding. The bottom sieve in the separator set №10. The passage of this sieve is received mealy fraction, which is sent to re-granulation. The passage upper sieve and descent sieve getting crumb. [ 12, 14, 15].

2. Biological value assessment compound feed in the form blend of crumbs. A biological experiment was conducted on the feed value of the test samples compound feed in the form blend of crumbs, on laboratory animals at the base of the biochemistry laboratory of the Institute of Dentistry and Oral and Maxillofacial Surgery of the Academy of Medical Sciences of Ukraine.

Research nutritional value was carried out on fifteen rats, Wistar lines (males, age - 1 month). For the experiment, three groups of white rats, five rats per group, were formed. The average rat weight was $52.6 \pm$ 1.7 g. (fig. 4)

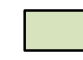


Scheme - A

Loose

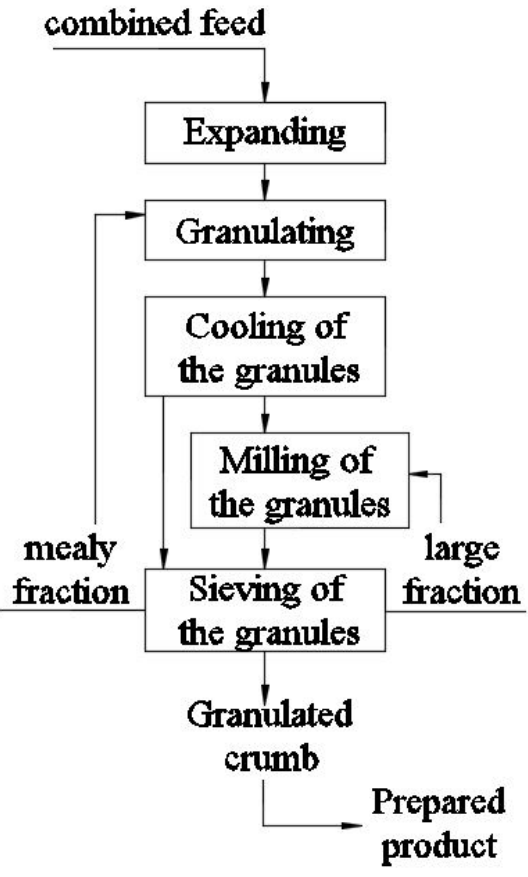

Scheme - B

Loose

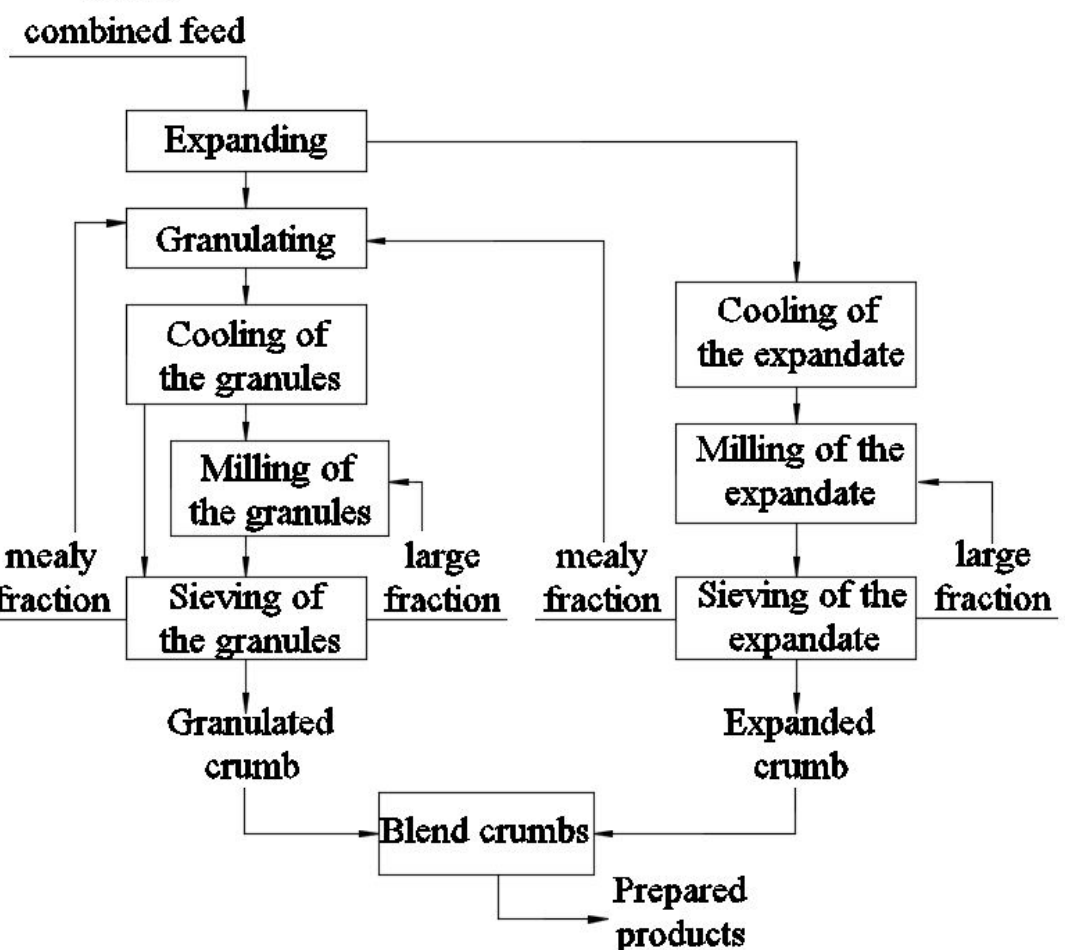

Fig. 3. Scheme A - Basic (traditional) technology production compound feed in the form granulated crumb. Scheme B - Advanced technology production compound feed in the form blend of crumbs.

For 8 days in the experimental groups, laboratory rats were fed diets of the following composition:

expanded crumb.

- Group rats №1 - received

- Group rats №2 - received granulated crumb.

- Group rats №3 - received compound feed in the form blend of crumbs, in relation to $1: 1$.

Growth rate in live body weight rats for 8 days of feeding is shown in fig. 5, which shows that, all groups gained weight during the experiment. In this case, rats of group №1 gained weight from $56.8 \mathrm{~g}$ to 61.0 $\mathrm{g}$, and group №2 from $51.2 \mathrm{~g}$ to $55.4 \mathrm{~g}$, that is, the average weight gain of rats of group №1 and №2 was $4.20 \mathrm{~g}$ / head. However, the best result was shown by group № 3. Because the rats gained weight from $51.2 \mathrm{~g}$ to $55.8 \mathrm{~g}$, and therefore the average weight gain of rats was $4.60 \mathrm{~g} /$ head, that is $9.5 \%$ more than group №1 and №2.

Thus, the average increase in live weight of rats for 8 days amounted to:

- $\quad$ Group rats №1 - $4.20 \mathrm{~g} /$ head for 8 days;

- Group rats №2 - $4.20 \mathrm{~g} /$ head for 8 days;

- $\quad$ Group rats №3 - $4.60 \mathrm{~g} /$ head for 8 days;

In fig. 3 shows consumption data for each group of rats.

Figure 3 shows that most of all, for the entire period of feeding, consumed rats of group №3 - 797 g,

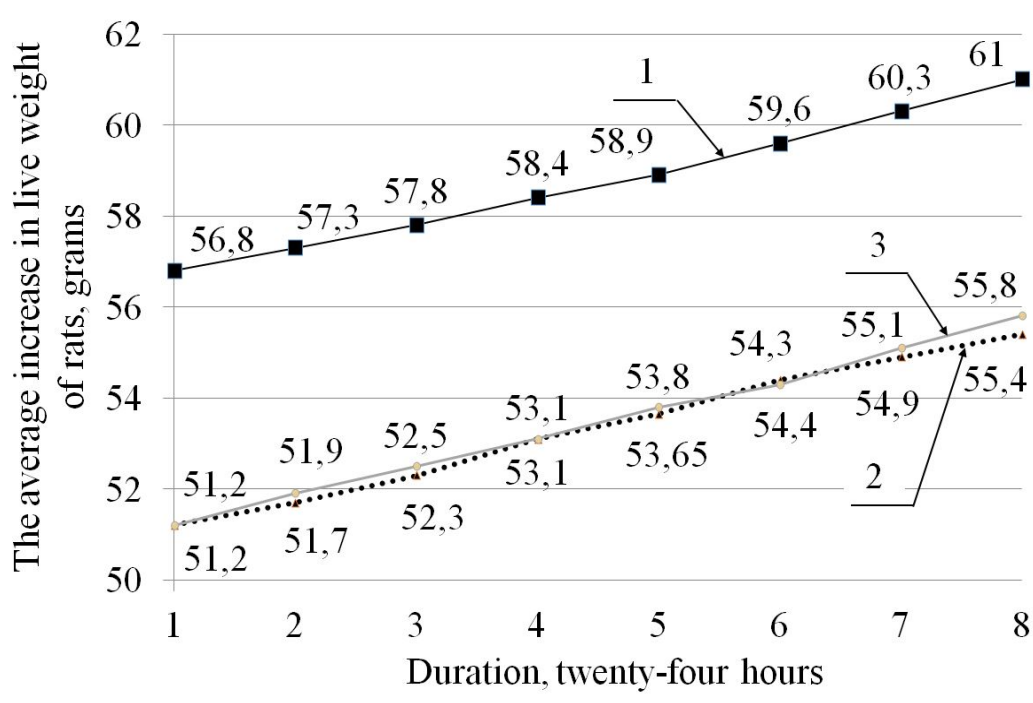

Fig. 4. The growth dynamics body weight of laboratory rats, breedWistar, throughout the experiment.

(1 - first group, 2 - second group, 3 - third group).

rats of group №2 - 749 g., and least of all rats of group №1 - $658 \mathrm{~g}$.

Table 1 summarizes all the data carrying out biological value assessments test samples. The least feed value showed sample №2 (granulated crumb) - $28.0 \mathrm{mg} /$ $\mathrm{g}$, the greatest feed value showed sample №1 (expanded crumb) - $31.9 \mathrm{mg} / \mathrm{g}$, this proves the effectiveness of increasing the feed value of products due to the expansion process. Feed value of sample № 3 (compound feed in the form blend of crumbs) overall also showed high results $-28.9 \mathrm{mg} / \mathrm{g}$. 


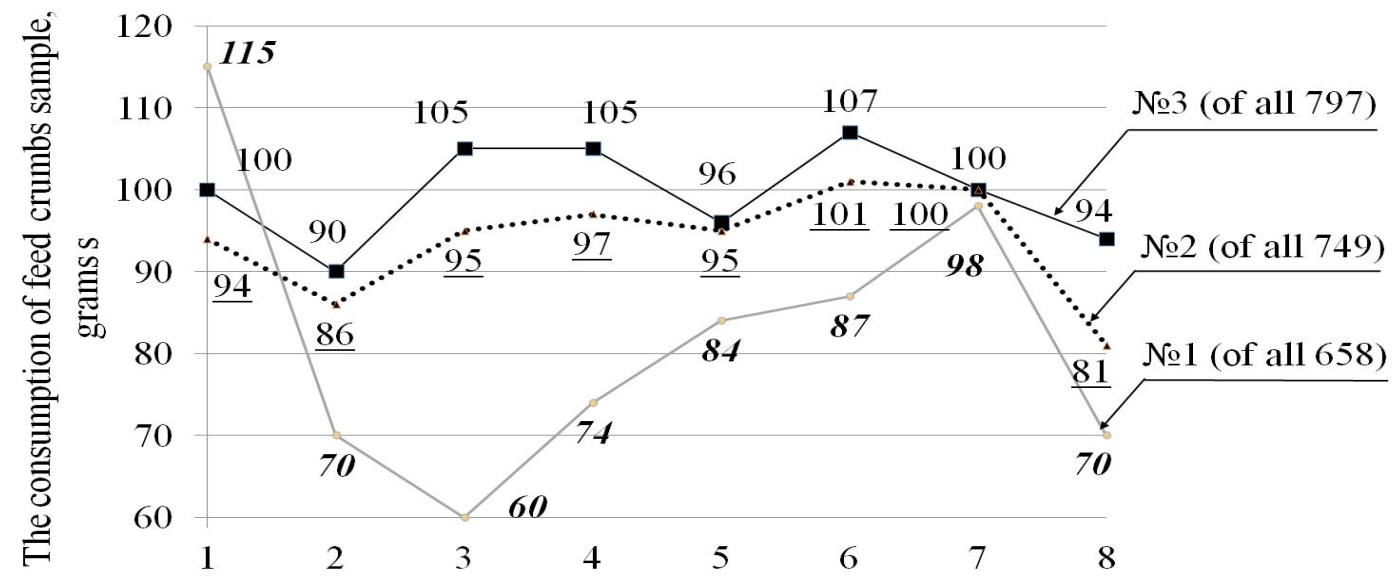

Duration, twenty-four hours

Fig. 5 - Dynamics of consumption of feed samples (1 - the first, 2 - the second group, 3 - the third group).

Table 1 - Assessment indicators biological value the test samples

\begin{tabular}{||l||c||c||c||}
\hline \multicolumn{1}{|c||}{ Indicators } & $\begin{array}{c}\text { №1 } \\
\text { (expanded crumb) }\end{array}$ & $\begin{array}{c}\text { №2 } \\
\text { (granulated crumb) }\end{array}$ & $\begin{array}{c}\text { oompound feed in the } \\
\text { form blend of crumbs) }\end{array}$ \\
\hline \hline $\begin{array}{l}\text { Feed consumption for the entire } \\
\text { feeding period, } g\end{array}$ & 658 & 749 & 797 \\
\hline \hline Feed intake per day, g & 82,25 & 93,63 & 99,63 \\
\hline \hline Feed intake per day (on 1 head), g & 16,45 & 18,72 & 19,92 \\
\hline \hline $\begin{array}{l}\text { The daily average mass gain of the rat } \\
\text { (per 1 head), mg }\end{array}$ & 525 & 525 & 575 \\
\hline \hline
\end{tabular}

Table 2- Indicators growth a broiler chickens

\begin{tabular}{|c|c|c|c|}
\hline \multirow[t]{2}{*}{ Indicators } & \multicolumn{3}{|c|}{ Group } \\
\hline & $\begin{array}{c}\text { №1 (Control) } \\
\text { traditional technology }\end{array}$ & $\begin{array}{c}\text { №2 (Research) } \\
\text { advanced technology }\end{array}$ & $\begin{array}{l}\text { Deviation from the } \\
\text { control, } \%\end{array}$ \\
\hline The safety of the poultry population, $\%$ & 96,3 & 98,7 & $+2,4$ \\
\hline \multicolumn{4}{|l|}{ Live weight of 1 head, $g$} \\
\hline Chicken (age 1 day) & $42,5 \pm 0,3$ & $42,3 \pm 0,4$ & $+0,5$ \\
\hline Chicken (age 7 day) & $92,3 \pm 2,2$ & $94,5 \pm 2,4$ & $+2,4$ \\
\hline Chicken (age 14 day) & $192,4 \pm 10,2$ & $195,3 \pm 10,1$ & $+1,5$ \\
\hline Weight gain, $g$ & 10149,9 & 1533,0 & +2,1 \\
\hline Daily average mass gain, $\mathrm{g}$ & 10,7 & 10,9 & $+1,9$ \\
\hline Feed costs per $1 \mathrm{~kg}$ of body weight gain, $\mathrm{kg}$ & 2,2 & 1,9 & $-13,6$ \\
\hline
\end{tabular}

The results obtained indicate a high biological efficiency of the developed compound feed in the form blend of crumbs in comparison with the classical method of feeding granulated crumb.

3. Assessment of livestock value compound feed in the form blend of crumbs. Zootechnical studies, to evaluate the productive action effectiveness compound feed in the form blend of crumbs for young broiler chickens, were carried out under industrial conditions of the "Grain Club". For the experiment, were formed two research groups of Cobb 500 cross broilers, control and experimental 30 goals each. The average live body weight of the bird in the control was $42.5 \mathrm{~g}$, in the experimental $42.3 \mathrm{~g}$.

Two groups of chickens received crumbs with a nutritional value that matched the organism chickens. In the first control group for feeding used the granulated crumb, obtained in the traditional way (loose feed was moistened, expanded, granulated, crushed and sieved with receipt granulated crumb). In the second experimental group used compound feed in the form blend of crumbs, which was obtained by advanced technology (finished products for feeding the second experimental group was compound feed in the form blend of crumbs).

The content, feeding conditions, composition of bulk feed were identical (except for the method of its preparation in crumb) namely: the first control group traditional technology receiving granulated crumb, second research group advanced technology receiving 
compound feed in the form blend of crumbs.

Compound feeds were produced according to a recipe developed by the specialists of the department of feed technology and biofuel of Odessa National Academy of Food Technologies.

Assessment of livestock performance using compound feed in the form blend of crumbs for feeding broiler chickens, developed on indicators such as livestock conservation, weight gain, daily average mass gain, feed costs per $1 \mathrm{~kg}$ of body weight gain. The results of livestock zootechnical research are shown in table 2 .

Chicken Broilers experimental group (age 7 day) in by weight were heavy, they were heavy than the control by $2.4 \%$, (age 14 day) were heavy than the control by $1.5 \%$. The safety of the poultry population at the end of the experiment was $96.3 \%$ in the control group, was $98.7 \%$ in the experimental group.

Feed consumption per $1 \mathrm{~kg}$ gain in weight in the experimental group was $13.6 \%$ less than in the control, daily average gain the research group is $1.9 \%$ larger than in the control. Thus, the assessment livestock value compound feed in the form blend of crumbs we can conclude.

It is proved that, technology that has been developed and improved for production compound feed in the form blend of crumbs, the technology is characterized by increased biological value and satisfies the physiological needs of young birds, compared with traditional production technology granulated crumb.

\section{Conclusions}

1. It was introduced into production advanced technology in production compound feed in the form blend of crumbs and determination of their zootechnical quality.
2. Has been developed biological value assessment compound feed in the form blend of crumbs.

3. Has been developed assessment of livestock value compound feed in the form blend of crumbs.

4. Experimental studies were conducted at the Odessa National Academy of Food Technologies.

5. Industrial approbation of the developed, advanced technology production compound feed in the form blend of crumbs, was done in industrial conditions of a branch of a public joint stock company "State Food and Grain Corporation of Ukraine" "Izyumsky plant bakery products".

6. A biological experiment was conducted on the feed value of the test samples - compound feed in the form blend of crumbs, on laboratory animals at the base of the biochemistry laboratory of the Institute of Dentistry and Oral and Maxillofacial Surgery of the Academy of Medical Sciences of Ukraine. For the experiment, three groups of white rats, five rats per group, were formed.

7. Zootechnical studies, to evaluate the productive action effectiveness compound feed in the form blend of crumbs for young broiler chickens, were carried out under industrial conditions of the "Grain Club". For the experiment, were formed two research groups of Cobb 500 cross broilers, control and experimental 30 goals each. The safety of the poultry population at the end of the experiment was $96.3 \%$ in the control group, was $98.7 \%$ in the experimental group. Feed consumption per $1 \mathrm{~kg}$ gain in weight in the experimental group was $13.6 \%$ less than in the control, daily average gain the research group is $1.9 \%$ larger than in the control.

\section{REFERENCES}

1. ANDRITZ. Process technologies, equipment, plants, and systems. [Internet. Website]. 2020. March [cited 2020 March 14] Available from: https://www.andritz.com/group-en.

2. IFIF. represents and promotes the global feed industry. The International Feed Industry Federation (IFIF) [Internet. Website]. 2020. March [cited 2020 March 1]. Available from: https://ifif.org/

3. Yegorov B.V., Malaki I.S. Technological bases of processing tomato pomace in feed additives. Ukrainian Food Journal. 2014; 3(2):228-235

4. Egorov B.V., Batievskaya N.A. Ways to reduce energy consumption in the production of mixed feeds. Abstracts of the Academic Conference of Teachers of the Academy. 2017; 1(77):14-16.

5. Purushotham B, Radhakrishna PM, Sherigara BS. Effects of Steam Conditioning and Extrusion Temperature on Some Anti-nutritional Factors of Soyabean (Glycine max) for Pet Food Applications. American Journal of Animal and Veterinary Sciences. 2007; 2(1): 1-5

6. Egorov B.V., Batievskaya N.A. Granulation - the key to profitability of production. Collection of scientific works of young scientists, graduate students and students. 2017; 1(1):29-30.

7. Danish Agriculture and Food Council. Agriculture and Food. 2010; 2(1): 170-174.

8. Egorov B.V., Batievskaya N.A. Improving the technology of granulation in the production of animal feed, ways to reduce energy consumption. Abstracts of the Academic Conference of Teachers of the Academy. 2018; 1(78):19-20.

9. Yegorov B.V., Batievskaya N.O. Application of granulation technology in various industries. Cereal products and feed. 2017; 17(3):33-38.

10. Rosentratel KA et al. Small-scale extrusion of com masa by-products. Cereal Chem. 2005; 82(4):436-446.

11. Jessica E., Foster K., How to feed the world. 1th ed. London; 2018

12. Purushotham B, Radhakrishna PM, Sherigara BS. Effects of Steam Conditioning and Extrusion Temperature on Some Anti-nutritional Factors of Soyabean (Glycine max) for Pet Food Applications. American Journal of Animal and Veterinary Sciences. 2007; 2(1): 1-5

13. Rules of organization and conduct of the technological process of production of feed products. MAKA, Kiev Institute of Bread Products, 1998

14. Method and technology of granulation: remaining available. [Internet]. 2020 February [cited 2020 February 25]; Available from: https://www.ncbi.nlm.nih.gov/pmc/articles/PMC4401168/

15. Gabriel I.M,. Mallet S.H., Leconte M.J. Differences in the digestive tract characteristics of broiler chickens fed on complete pelleted diet or on whole wheat added to pelleted protein concentrate. British Poultry Science; London; 2003. 
Б.В. Егоров, докр. т.н, проф. , E-mail: bogdanegoroff58@gmail.com https://orcid.org/0000-0001-7526-0315, ResearcherID: Q-1365-2015, Scopus Author ID: 56578802600

Н.О. Батієвська, аспірант, E-mail: natabatievskaya@gmail.com

https://orcid.org/0000-0002-9380-2891, ResearcherID: J-5254-2015

${ }^{1}$ Одеська національна академія харчових технологій, вул. Канатна, 112, Одеса, 65039, Украйна

Кафедра технологии комбикормов и биотоплива, Тел. +048-712-40-88

\title{
ОЦІНКА ЯКОСТІ КОМБІКОРМІВ У ВИГЛЯДІ СУМІШІ КРУПОК
}

\begin{abstract}
Анотація
У статті представлено способи попередньої волого-теплової підготовки комбікорму, зокрема застосування експандування перед процесом гранулювання, як основу для подальшої розробки удосконаленої технології гранулювання. Вплив волого-теплової обробки на засвоюваність поживних речовин окремих інгредієнтів комбікорму було предметом багатьох досліджень. Загалом, волога-теплова обробка комбікорму дозволяє покращити засвоюваність поживних речовин, включаючи білки, амінокислоти і вуглеводи.

Поставлена мета роботи, та завдання досліджень. Метою роботи було впровадження у виробниитво удосконалену технологію виробничтва комбікормів у вигляді суміші крупок та визначення їх зоотехнічної якості. Узагальнення проведених аналітичних та експериментальних досліджень дозволило розробити удосконалену технологію гранулювання у вигляді суміші крупок, яка дозволить збільшити випуск готової продукиії.

Було проведено оцінку біологічної цінності та оцінку зоотехнічної цінності комбікормів у вигляді суміші крупок. Були проведені відповідні дослідження. Експериментальні дослідження проводили в Одеський Національній академії харчових технологій. Промислову апробацію розробленої удосконаленої технології виробництва комбікормів у вигляді суміші крупок проводили у промислових умовах підприємства філії публічного акиіонерного товариства "Державна продовольчо-зернова корпорація Украӥни" "Ізюмський комбінат хлібопродуктів".

Було проведено біологічний експеримент на лабораторних тваринах на базі лабораторії біохімії Інституту стоматології та щелепно-лицевої хірургії НАМН України. Зоотехнічні дослідження з оцінки продуктивної дї ефективності комбікормів у вигляді суміші крупок для молодняку курчат-бройлерів проводили у промислових умовах ТОВ «Зерновий клуб». Таким чином, ефективність використання комбікорму у вигляді суміші крупок, оиінювали у дослідах на білих щурах лінії Вістар (біологічна очінка) і на курчатах-бройлерах кросу Кобб 500 (зоологічна оцінка).
\end{abstract}

Ключові слова: комбікормова промисловість, очінка якості, технологія гранулювання, гранульована крупка, експандована крупка, комбікорми у вигляді суміші крупки.

\section{ЛITEPATУРA}

1. Process technologies, equipment, plants, and systems // ANDRITZ: [Website]. 2019. URL: https://www.andritz.com/group-en (viewed on: 10.12.2018).

2. IFIF represents and promotes the global feed industry // The International Feed Industry Federation (IFIF) : [Website]. 2019. URL: https://ifif.org/ (viewed on: 25.12.2019).

3. Yegorov B., Malaki I. Technological bases of processing tomato pomace in feed additives // Ukrainian Food Journal. 2014. V. 3. №2. P. 228-235.

4. Сгоров Б.В., Батієвська Н.О. Способи зменшення споживання енергї у виробництві комбікормів // Тези доповідей Академічної конферениії викладачів Академії. 2017. T. 1, вип. 77. С. 14-16.

5. Purushotham B., Radhakrishna P.M., Sherigara B.S. Effects of Steam Conditioning and Extrusion Temperature on Some Antinutritional Factors of Soyabean (Glycine max) for Pet Food Applications // American Journal of Animal and Veterinary Sciences. 2007. V. 2. №1. P. 1-5.

6. Сгоров Б.В., Батієвська Н.О. Гранулювання - запорука прибутковості виробництва // Збірник наукових праць молодих учених, аспірантів та студентів. 2017. T. 1, вип. 1. С. 29-30.

7. Danish Agriculture and Food Council // Agriculture and Food. 2010. V. 2. №1. P. 170-174.

8. Сгоров Б.В., Батієвська Н.О. Удосконалення технології гранулювання при виробництві комбікормів, шляхи зниження енерговитрат // Тези доповідей Академічної конферениії викладачів Академії . 2018. T. 1, вип. 78. С. 19-20.

9. Yegorov B.V., Batievskaya N.O. Application of granulation technology in various industries // Зернові продукти і комбікорми . 2017. T. 17, вun. 3. C. 33-38.

10. Rosentratel K.A. et al. Small-scale extrusion of com masa by-products // Cereal Chem, 2005. V. 82(4). P. 436-446.

11. Jessica E., Foster K., How to feed the world. 1th ed. London; 2018

12. Purushotham B., Radhakrishna P.M., Sherigara B.S. Effects of Steam Conditioning and Extrusion Temperature on Some Antinutritional Factors of Soyabean (Glycine max) for Pet Food Applications // American Journal of Animal and Veterinary Sciences. 2007. V.2. No1. P.1-5.

13. Правила організації і ведення технологічного процесу виробництва комбікормової продукиї . МАКУ, Київський інститут хлібопродуктів, 1998. $220 \mathrm{c}$.

14. Методи та технології гранулящї: останні досягнення [Електронний ресурс] / Доступ: https://www.ncbi.nlm.nih.gov/pmc/articles/PMC4401168/

15. Gabriel I.M,. Mallet S.H., Leconte M.J. Differences in the digestive tract characteristics of broiler chickens fed on complete pelleted diet or on whole wheat added to pelleted protein concentrate. British Poultry Science; London; 2003.

$\begin{array}{ll}\text { Received 26.12.2019 } & \text { Revised } \\ \text { Reviewed 03.02.2020 } & \text { 21.03.2020 }\end{array}$

Reviewed 03.02.2020

Cite as Vancouver Citation Style

Batievskaya N., Yegorov B., Quality assessment of compound feeds in the form of mixture crumbs. Grain Products and Mixed

Fodder's, 2020; 20 (1, 77): 41-47. DOI:

Cite as State Standard of Ukraine 8302:2015

Quality assessment of compound feeds in the form of mixture crumbs / Batievskaya N. et al. // Grain Products and Mixed Fodder's. 2020. Vol. 20, Issue 1 (77). P. 41-47. DOI: 